\title{
Improving Students’ Speaking Skill Through CLT An Action Research
}

\author{
Anggraini \\ AMIK BSI BOGOR \\ Jl. Raya Merdeka no. 168 Bogor \\ Email: anggraini.ngg@bsi.ac.id
}

\begin{abstract}
This is an action research study that aimed to improve students' speaking skill through communicative language teaching technique. It discusses how is communicative language teaching technique can improve students' speaking skill. Private language schools, on other hand, tend to be better equipped than some goverment schools (thought his not always the case), at English training course students' speaking skill is still low especially in basic level. The students of english training course find the difficulties in speaking skill; the students have felt boring with the old technique in improving their speaking skill. In the class room action research the writer uses the picture reconstruction, and students have to discuss and tell in their group, each group contain of 4 until 5 students, the writer made three cycles, and the writer gives the score each cycle according to the speaking measurement.Based on the result research and concluded that the students can improve their speaking skill through communicative language teaching technique. In the first cycle the average students' score is 60, in the second is 70 point, and in the last cycle is 80 point, and writer has made a graphic of each cycle.
\end{abstract}

Key Word: Action research, Speaking, CLT

\section{INTRODUCTION}

English is one of the language in the world plays an important role in many various fields, as many people try and strive to master this language, so that can easily graps the information and communicate to each other. In english language teaching, we recognize the four of skills, those are: listening, speaking, reading and writing. All those skill are very important for those who want to master the English. (Harmer, 2007)

In Indonesia English language is English is the first foreign language, which is taught to the students of primary or secondary school of Indonesia,All around the world, students of all ages re learning to speak English, but their reason are for wanting study english can differ greatly. A huge number of the students learn English in primary school around the world. They have not chosen to do these themselves, but learn because english is on curriculum. (Harmer, 1998)

Good speaking activities can and should be extremely enganging for the students. If they all are participating full and if the teacher has set up activity properly and can give symphetic and useful feedback, they will get tremendous satisfaction from

We need to be clear that the kinds of speaking activities are not the same as controlled language practice, where, for example, students say a lot of sentences using a particular pieces of grammaror particular funtion. A good english teacher should be able to organize teaching learning activities, they have to give materials using suitable techinque. A good technique maymake students understand and master the lesson.

Mastering speaking skill is very important for the students in order to make the student are able to communicate in English with other people from others country easily especially if they want to go abroad, it is obligation for them to be able to communicate in English since English is applied as the first international language in countries all over the world. More over Indonesia is now being one of the ASEAN free trade countries which means that if they cannot master speaking well, they will never be able participate with.There are many problem related to improve students' speaking skill, most of the students were not really motivated in speaking task. (Saputra, 2015).

Private language schools, on the other hand, tend to be better equipped than some goverment schools (though his is not always the case), they frequently have small class sizes, and crucially, the students in them may be well have chosen to come and study this will affect their motivation at the beginning of the process. At english training course students' speaking skill is still low especially in basic level. The writer so interested, to teach english language at English course, because in this course the students have more chances to develop or increase their potency and knowledge in connection with English.

The students of english training course find the difficulties in speaking ability, the students have felt boring with old technique, and so the writer chose the communicative language teaching especially in improving students' speaking skill and writer proposes a research problem that is" improving students' speaking skill through communicative language teaching technique an action research at English training course.

Based on the discussion above,then the researcher try to make use of Communicative Learning Teaching (CLT) to solve the existing problem.

It is because during learning process of CLT, students' are hoped to communicate orally and 
conquer all components of communicative competence and teacher is being motivator, assessor, facilitator, and corrector during students' discussion or speaking in front of the class. In addition, the teacher also should make their lesson interesting so the students don't fall asleep during learning English (Harmer, 1998). Learning activities in CLT focuses on real oral communication with variety of language without too focus on form of grammatical patterns if distinguished with noncommunicative activities which only focus on how to construct the sentences that based on terms of grammatical during learning process of English (Harmer, 1998).

In relation with CLT to teach speaking, research has shown that CLT can be used to improve students' speaking skill (Efrizal, 2012). Thus, based on its benefits for English learning and other good values of the use of CLT, in order to enrich the research, this study is then proposed to improve the speaking skill for the students of English Training course.

\section{A.Speaking}

Speaking the faculty of oral communication is significant to an individual's living processes and experiences as are the faculties of seeing and walking. Without speaking, people must remain in almost total isolation from any kind of society. Here people wish to emphasize that they are not thinking of "speaking" solely terms of formal occasions as public speaking as frequently conveived. People are, rather thinking of those many, and very important, daily experience when they speak to other persons for purposes that range from simple to complex communication.

As stated before in the first chapter that speaking is one of the four skills which play a significant role mastering English. It is the most complex skill than the three skills in performing it and learning it, not only does people deal with their cognitive basic to learn the forms of language, but also deal with internal inside themselves. In finding out whether some phychological problem in particular, the feeling of inferiority may affect the students in learning the english speaking skill, it is obviously significant to know what speaking is and some matters that are connected with it.

Speaking is a skill of convey words sounds of articulation to express or to deliver ideas, opinion, or feeling. Therefore, there are purposes (kinds) of speaking, namely to inform to persuade, and to entertain" from this definition, it is clearly seen that speaking is the process of sharing with another person, or with other persons, one's knowledge, interest, attitudes, opinions, or ideas. In addition, delivery of ideas, opinions, or feeling is some important aspects of the process of oral communication trough which a speaker's conception become actual to him and his audience.
Speaking is one way to communicate with ideas and though a message orally. To enable students to communicate, we need to apply the language in real communication. According to (Ricckheit, 2005) speaking is speech or utterances with the purpose of having intention to be recognized by speaker and the receiver processes the statements in order to recognize their intentions.

Speaking, as one of the English language skill has some aspects. According to Spratt, there are four aspects of speaking,they are: fluency, pronunciation,grammatical accuracy, and body language. Furthermore,explains that fluency is speaking at a normal speed, without hesitation,repetition or self- correction, and with smooth use of connected speech. Meanwhile, accuracy in speaking is the use of correct grammar, vocabulary and pronunciation. According to (Jones, 2007) fluency means using simple words to express meaning, even though longer words might be more descriptive.

Also, fluency means speaking slowly and clearly, not speaking fast and unclearly. Fluency depends on knowing more vocabulary and on confidence - and on not worrying about losing face by making mistakes. Another component of fluency is being able to articulate easily and comprehensively.

Meanwhile, Accuracy means not making too many mistakes. We certainly want our students to become more fluent, but we also want them to become more accurate. An overconfident, inaccurate speaker can be an irritating companion, though preferable to a silent one. In addition (Lan, 2010) state that fluency may be defined as the ability to get across communicative intent without too much hesitation and too many pauses to cause barriers or abreakdown in communication.

Meanwhile,accuracy refers to the use of correct forms where utterances do not contain errors affecting the phonological, syntactic, semantic or discourse features of a language. From above description, it is known that accuracy and fluency are closely related, which leads us to the notion that accuracy as well as fluency is necessary for successful communication.

The aim of teaching speaking in our life, we easily see that everybody moves to do their activities to get what they want and need. Some of them go to office to work and finally get salary. Students go to school to study hard because they want to pass the examination. A child acts politely and warmly because he want to get a prize from his father. A mother treats her child mercifully because she wants him to grow ip and become a wise man. In short, everybody has some purposes when he or she does an activity or when people do something; they have aims with it. It also happen when someone speaks to others. He or she has aims. These aims are relatively intended to get easy in communication. Because the easiest way of 
communication is by speaking. $\mathrm{B}$

\section{B. Communication Language Teaching Tecnique}

CLT itself started in the late 1960s and continues to evolve. It is not actually a method but an approach to teaching based on the view that learning a language means learning how to communicate effectively in the world outside the classroom. It developed mainly as a reaction to the limitations of previous methods which put little, if any, emphasis on the ability to communicate or interact. It was also influenced by developments in the way the language was described

taking into account the communicative function of language, that we use language to do things like suggest, invite, agree, request,criticize, predict, and so on (Richard, 2001)

The communicative language teaching (CLT) is an integration of skill thought and learned with a communicative view. CLT means to teach a language in such a way that the learners can communicative with other people in real life situations. The learners who learn English language want to be able to communicative socially on an everyday basis with native or very able non native English language speakers. The concept of communicative competence was first introduced by Hyme in Europe in the mid 1960s and many researchers have helped developed theories number of new approaches developed.

(Richard, 2001) give the principles of CLT in the classroom procedures:

1. Learners learn a language through using it to communicative.

2. Authentic and meaningful communication should be the goal of class room activities.

3. Fluency is an important dimension of communication.

4. Communication involves the integration of different language skill.

5. Learning is a process of creative construction and involves trial and error.

According to Richards \& Rogers view above, communicative language teaching refers to communicative. Teacher can gives the opportunity to talk about their reading in the classroom with real life context. Activities will build mental and skill of students to communicative.

Referring to the above points, CLT is an approach that requires practice. In Improving students' speaking skill through CLT; students are encouraged to actively communicate in the classroom.

\section{C.Theory of Action research}

This research employed Classroom Action Research (CAR) design. The purpose of conducting CAR was to solve the problems happened in the classroom that is faced by the students. This was in line with the description on the background of study. One of the

problems faced in the classroom was learning achievement in speaking skill. Hence, by doing Classroom Action Research (CAR), hopefully the researcher got the improvement of learning quality in the classroom as learning achievement in speaking skill. In line with this, (Latief, 2008) argued that Classroom Action Research is the research design that is constructed for improving the quality of learning in the classroom.

Classroom Action Research, initially a researcher identifies problems which happens in teaching learning process, then sets the plan, design a way to solve problems, and implements the plan. Therefore, the researcher focuses on a particular classroom aiming at finding the solution for the problems takes place there.

Action research is development tool for teacher that involves observing or gathering other data about a class throught interviews, case studies, and questionaries. A teacher can establish a cycle of identifying problems, planning changes in response, implementing changes and gathering and analyzing data to evaluate the implementation.” Action research can be used to help general development or to resolve specific problems with teaching or learners.

Example, a teacher has problems with giving feedback to learners on speaking problems and decides to record their classes. They then analyze the recording to identify more effective ways or correction. They implement changes based on this, and collect data to analyze whether feedback is now more useful to learners.

Stephen Kemmis has developed "a simple model of the cyclical nature of the typical action research process. Each cycle has four steps: planning, acting, observing, reflecting” (Kemmis, 1992)

\section{Planning}

Three defining characteristics of action research are that it is carried out by practitioners for our purposes, classroom teachers rather than outside researchers.secondly, that is collaborative. And thirdly, that it is aimed at changing things." A distinctive feature of action research is that those affected by planned changes have the primary responsibility for deciding on courses of critically informed action which seem likely to lead to improvement, and for evaluating the results of trategies tried out in practice. (Nunan, 1992)

\section{Acting}


A piece of descriptive research carried out by a teacher in his or her classroom, without the involvement of others, which is aimed at increasing our understanding rather than changing the phenomenon under investigation, would not be considered by these commentators to be action research.

\section{Observing}

They are many steps in observes an action research;

Step 1: Initation: A teacher comes to me with a problem; his current group of students do not seem intested or motivated.

Step 2: Premilary: we spend some time collecting baseline data that trought observation and recording classrom interaction.

Step 3: Hypothesis: after reviewing the initial data, we form the hypothesis that the students are unmotivated because the content of the classroom is not addressing the needs and interest of the students.

Step 4: Intervention: the teacher devises a number of strategies for encouraging the students to relate the content of the lessons to their own backgrounds and interest. These include increasing the number of referential over display question.

Step 5: Evaluation: After several weeks, the class is recorded again. There is much greater involvement of the students, and the complexity of their language and the student led interactions in enhanced.

Step 6: Dissemination: the teacher runs a workshop for collegues and presents a paper at a language conference.

Step 7: Follow up: the teacher invitages alternative methods of motivating students.

\section{Reflecting}

In this section is discussed how to get started in a process of action research and reflection. The first step is usually identifying an idea.this may start out as a general idea. You do not have to be too ambitious at first, all right suggests that a good place to start may be explored simply by getting students to discuss it is in class.

As far as action research is concerned there is often no need for a radical change in what you do in the classroom. Becoming a researcher does not mean stopping being a teacher.

5. The advantages of action research

a. It can be used to investigate any issue of concern.

b. As a tool it is versatile and easy to use.

c. It promoted shared understanding and approaches.

d. Action are developed within, and foe, a specific school enviroment and so are more likely to succed.

e. Members of the school community are more committed to actions that they themselves develop, share and monitor.

f. Actions are defined and improved through the cycle of research .

g. Change is owned and managesd by participants.

h. Students,administator teachers parents and other can take a part.

i. Collaboration builds trusts and support.

j. It can start small and support.

k. It can start small and grow time.

l. Outside help and expertise can be invited in.

\section{THE RESEARCH FINDING AND ANALYSIS}

English Training course has some facilitators to support the activity in that institution such as audio visual class, teacher's room, all of classes begin in the morning until evening in addition, it has outing program such as moving class, visiting class, and Sunday meeting.

The writer interests to perfrom an action research at English Training Setu-Tangerang to knowing how far the student's ability in speaking English through comubication language teaching technique for basis level.

\section{A. The Process Of The Research}

\section{Observation}

The observation includes the English teacher and the students at English Training Course Basic level.Teacher gives picture reconstruct to the students. Students make group of four or five, each group get part of the picture reconstruct. Each member of the group has to discuss and tell the picture story reconstruct.

\section{Interview}

Interview with English teacher as key informant and the students as informant is used to get more information in anything that interrelated with speaking class, especially in CLT, and the assessment process with in structural instrument as questionnaire which is applied in interview and direct practice of evaluate the students' ability. Realization of processing data collection is occurred by the writer and helped by the English teacher.

B. Teaching Speaking through Communication Language Technique

1. Preparation of Teaching Speaking through Communication language teaching Technique.The writer done preparation by doing routine activity such as absent of the 
entire student, prepare the subject materials are going to discuss.The teacher has the lesson planning before they are teaching in the classroom. the teacher divided the class into several groups that consists of 3 to 4 students.

2. Teaching Learning Process.

The writer teaches speaking through communication language technique at the basic level of English training course setuTangerang.In teaching speaking through CLT technique, firstly the students is guided to activate what they know that will help them understand what they speak, make prediction, and set purposes.Then, the writer made small groups, each group consists of 3-4 students, the teacher gave the picture and explained what the students should do. The teacher gave clear instruction about the task and selected one team leader for each group. Students are given different parts of a picture story; they have to reconstruct the whole narrative even though individually they have to seen only a small part of it. This is done because each member of the group has seen a different picture; by talking about their pictures together the narrative emerges. Here is a procedure for the technique.

\section{RESULT AND DISCUSSION}

\section{a. Cycle 1}

Reconnaissance

In this first cycle, the writer wants to improve the students' motivation first, because in this level the students's motivation in speaking skill is too low. The reasonable to suggest that the motivation that student bring to class is the biggest single factor affecting their success the students' vocabulary in this class have to improve too because their vocabulary in this class have to improve too because their vocabulary is still less. So the writer gives some vocabularies that have correlation with the picture reconstruction.

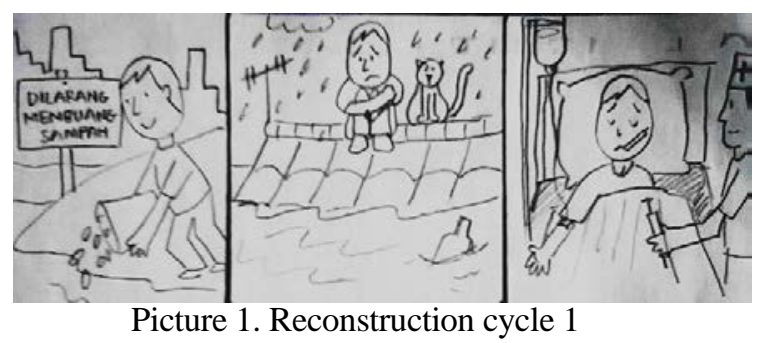

Planning

The writer makes the first lesson plan before going go to the classroom. The lesson plan contains of the step how to teach speaking according CLT technique.

Acting
The student is devided into five groups and each group consists of three until five students. Each group is given of the following picture and told to study it. After a couple of minutes the teacher takes the pictures back from the group, the teacher makes new groups( one from $\mathrm{A}$, one from group $\mathrm{B}$, one from group $\mathrm{C}$, one from group $\mathrm{D}$ ). The students in the new group have to try and recontruct the story bu discussion what they saw on each picture. The teacher then gets the different groups to tell their stories.

\section{Observing}

At the first, the students are not confident in their speaking skill, and the students be given enough time to prepare. As the students build their confidence and the classroom environment becomes more free and active, the teacher could gradually increase the difficulty and make the game more versatile. To motivate and encourage the students, give the point to the best student and groups each time.

\section{Reflecting}

To reflect this matter, the students must build their self confidence and the classroom atmosphere comfortable, in order to have real life communication.the result of the first cycle is not satisfied enough, so the writer has to improve the students' ability and self confidence.

\section{Cycle 2}

Reconnaissance

From the first reconnaissance in the cycle 1 the writer still finds some problem they are: the students' motivation, vocabulary and self confident are still low, and the students' speaking skill is still low too.in the second lesson plan the writer wants to improve the students' motivation, vocabulary and speaking ability.
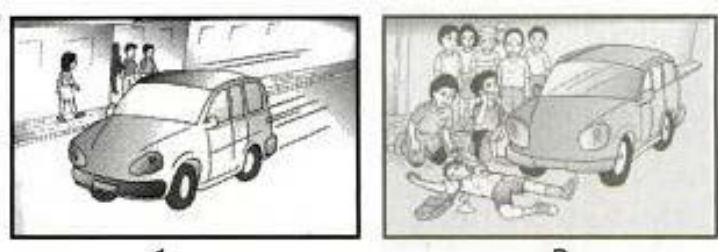

1

2
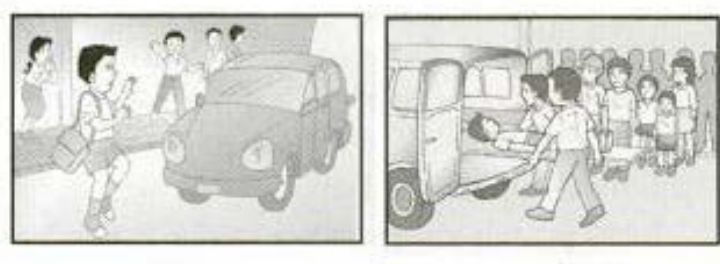

Picture 2. Reconstruction cycle 2

Planning

In the second cycle, the writer makes the second lesson plan, the lesson plan contains of step of how to teach speaking according discussion technique with different pictures. 
Acting

Each group of the students is given different picture, and told to study it, and discussion it their group. After a couple minutes the teacher takes the pictures back from the group, the teacher makes new groups (one from group A, one from group B, One from group $\mathrm{C}$, and one from $\mathrm{D}$ ). The students have to recontruct the story by discussing what they saw on each their picture .then the teacher gets the different groups to tell their story, often with picture sequences there will be more than on version of the story. The teacher yhen shows the students all of the picture.

Observing

The writer observes the students' speaking skill and their selfconfident. In the second they motivated by giving the points or score in each group.

Reflecting

The result in the second cycle is the students already have improved their speaking ability and their self confident. Even though, they do it for getting more point or score, but the writer convinced that that step by step the students are going to improve their speaking ability.

\section{Cycle 3}

Reconnaissance

From the second reconnaissance the writer has found the improvement in students' speaking ability, and the students' motivation. In grammatical the students still have problem, they can not use good sentences in grammar but it is not be big problem.
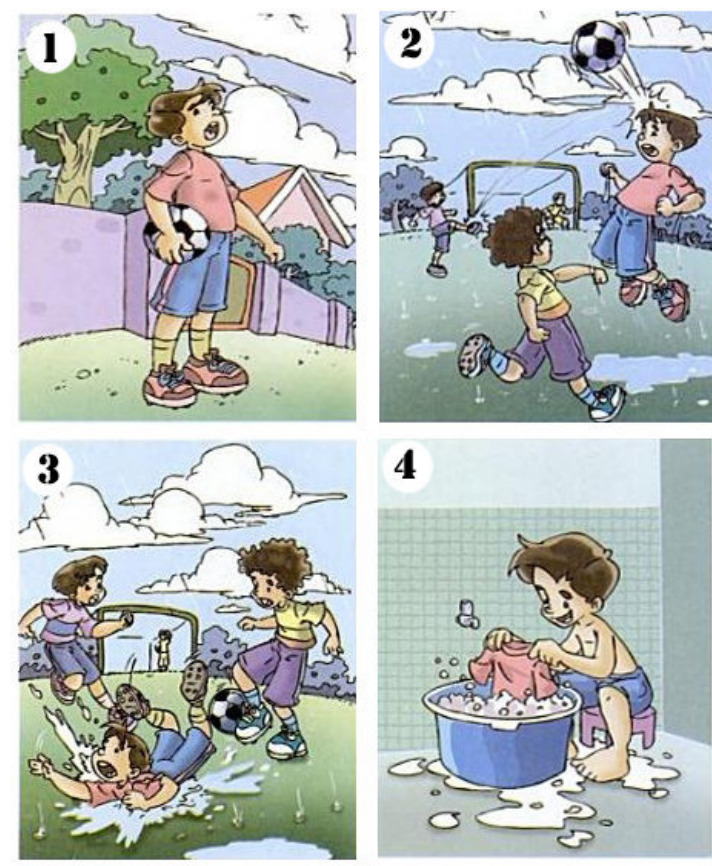

Picture 3. Reconstruction cycle 3

Planning

The lesson plan is prepared for the third cycle. The students have to prepare to give an opening in their performance.

\section{Interpreting data}

From the action research that the writer done, there are some improvements from the first cycle until the third cycle, so the writer makes scoring according the cycles. In the first cycle the writer gives sixty point, average from each group, in the second cycle the writer gives seventy points. And the last cycle the students' score eighty points. This is the score graphic:

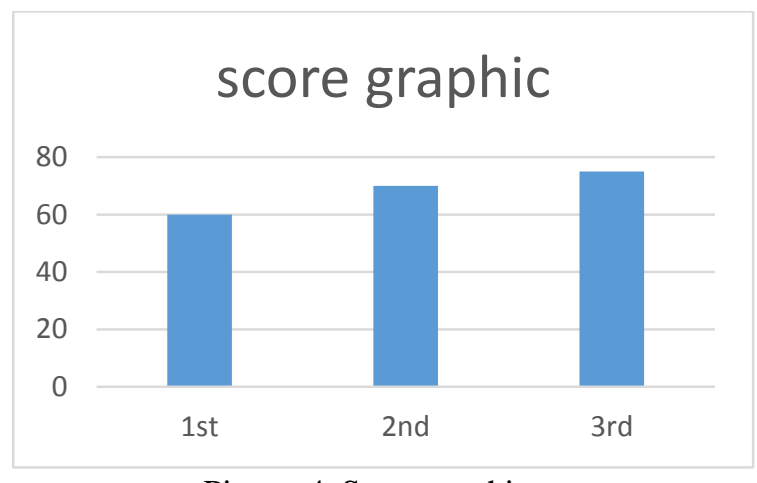

Picture 4. Score graphic

\section{IV.CONCLUSION}

Based the result of the research, the writer has some following conclusion; the interested techiques in teaching learning process by using communicative language teaching will help students in receiving material especially speaking. There is significant difference or the influence of communicative language teaching usage, to the students' achievement in learning speaking. To improve the students' speaking skill, communicative language teaching is very easy to understand by students and it is an efficient method. The writer offers communicative language teaching as a tool of teaching speaking for some reasons: first, the techique gives student's ideas easily; second the students are able to know and understand how to speak.

\section{REFERENSI}

Efrizal, D. (2012). Improving students' sepaking Trough Communicative Language Teaching Method at MTS Ja-alhaq. International Journal of Humanities and Social Science.

Harmer, J. (1998). How to Teach English: An Introduction to Practice of English Language Teaching. Newyork: Longman.

Harmer, J. (2007). The Practice of English Language Teaching. Pearson Longman.

Jones, L. (2007). The Student-Centered Classroom. Newyork: Cambridge University press. 
Kemmis, S. a. (1992). The Action Research Planner 3rd edition. Deakin University.

Lan, L. (2010). Fluency And Accuracy in Spoken English - Impication for classroom practice in bilingual context.

Latief, M. (2008). Penelitian Tindakan Kelas Pembelajaran Bahasa Inggris. Universitas Negeri Malang.

Nunan, D. (1992). Research Method in Language. Cambridge: Cambridge University Press.

Ricckheit, G. a. (2005). Hand Book of Communication Competence. Berlin: Moutende Gruyter.
Richard, J. a. (2001). Approaches and Method in Language Teaching. Cambridge University press.

Saputra, B. J. (2015). Communicative Languange Teaching. Premise Journal.

\section{Author Profile}

Anggraini,M.Pd was born in Sawahlunto, 19th December 1985. She graduated from STKIP Kusuma Negara Jakarta majoring English Education and Post gradute program state university of Indra Prasta PGRI Jakarta majoring master of English Education. She has been teaching for almost 8 years. Now she is a lecturer at AMIK BSI Bogor. 